\title{
Transient Expression of Chi42 Genes from Trichoderma asperellum in Nicotiana benthamiana by Agroinfiltration
}

\author{
Nguyen Quang Duc Tien ${ }^{1 \dagger}$, Phung Thi Bich Hoa ${ }^{1,2 \dagger}$, Nguyen Hoang Tue ${ }^{1}$, Dang Van Thanh ${ }^{1}$, Hoang Anh Thi $^{1}$, Nguyen \\ Ngoc Luong ${ }^{1}$, Nguyen Xuan Huy ${ }^{2 \dagger}$ and Nguyen Hoang Loc ${ }^{1 *}$ \\ ${ }^{1}$ Institute of Bioactive Compounds and Department of Biotechnology, University of Sciences, Hue University, Hue 530000, \\ Vietnam \\ ${ }^{2}$ Department of Biology, University of Education, Hue University, Hue 530000, Vietnam \\ *For correspondence: nhloc@hueuni.edu.vn \\ Contributed equally to this work and are co-first authors \\ Received 18 February 2021; Accepted 26 April 2021; Published 10 June 2021
}

\begin{abstract}
The present study reports the transient expression of chi42 genes encoding $42 \mathrm{kDa}$ chitinase from T. asperellum SH16 in $N$. benthamiana via agroinfiltration. The efficacy of agroinfiltration for chi42 genes including a wild-type gene (Chi42) and two synthetic genes (syncodChi42-1 and syncodChi42-2) was determined. Accordingly, coinfiltration of two vectors pMYV719 carrying one of three genes chi42 and pMYV508 carrying gene p19 expedited the higher expression of recombinant enzymes whose genes were optimized for codon usage in plant tissues. The highest chitinolytic activity of about $290 \mathrm{U} / \mathrm{mL}$ was found in plants containing the gene syncodChi42-2 after 7 days of injection, 1.7 and 2.6 times higher than that of genes syncodChi421 and chi42. Recombinant chitinase has also exhibited activity against the pathogenic fungus Sclerotium rolfsii under in vitro condition. A higher expression level of syncodChi42-2 gene in N. benthamiana and its antifungal activity promise potential applications in the field of transgenic crops against phytopathogenic fungi. (C) 2021 Friends Science Publishers
\end{abstract}

Keywords: Agroinfiltration; 42 kDa chitinase; chi42 gene; Transient expression; Trichoderma asperellum

\section{Introduction}

Agroinfiltration is a simple method of gene transfer by either syringe infiltration or vacuum infiltration of Agrobacterium tumefaciens or plant virus harbouring the target gene to monitor transient expression of this gene in plants (Leuzinger et al. 2013; Del Toro et al. 2014). The method commonly applied in agroinfiltration is the use of a needleless syringe to inject Agrobacterium into the underside of leaves (Santi et al. 2008). Syringe infiltration has been optimized for several plant species (Wroblewski et al. 2005) and has demonstrated several critical advantages (Chen et al. 2013). This method is considered as an alternative to stable transformation for large-scale production of proteins, enzymes and biopharmaceuticals (Chen and Lai 2015; Goulet et al. 2019).

Agroinfiltration studies have helped to better understand some biological processes such as gene expression, role of the promoters, interactions between proteins, function of proteins and metabolisms in plants (Chen et al. 2013; Guy et al. 2016). Currently, the agroinfiltration method is being applied for model plants (e.g., N. benthamiana Domin, Arabidopsis thaliana Heynh., tomato (Lycopersicon esculentum Mill.) and tobacco (Nicotiana tabacum L.)) and for crop plants (e.g. soybean (Glycine max Merr.), onion (Allium cepa L.), cowpea (Vigna unguiculata Walp.), grapevine (Vitis vinifera L.), rice (Oryza sativa L.), cacao (Theobroma cacao L.) and common bean (Phaseolus vulgaris L.)) (Shamloul et al. 2014; Suzaki et al. 2019). The agroinfiltration efficiency depends on different plant species, high levels of expression of the target gene could be obtained in $N$. benthamiana and $N$. tabacum while no such results were found in hemp and many other species (Deguchi et al. 2020). Agroinfiltration is usually carried out on the underside of the leaves, but in some cases, the thick epidermis limits the success of this method as A. tumefaciens cannot infect the leaf cells (King et al. 2015).

Chitinase (E.C 3.2.2.14) is enzyme that degrades chitin which is a primary constituent of fungal cell walls and exoskeletons of some animals such as insects and crustaceans (Sámi et al. 2001). Different chitinases were found in many fungal species of Trichoderma and used for biological control due to their mycolytic activity (Mohamed et al. 2010; González et al. 2012; Aoki et al. 2020). Besides, fungal chitinase genes were also used for improving resistance of plants to pathogenic fungi with the help of 
genetic manipulations (Lorito et al. 1998; Emani et al. 2003; Limón et al. 2004; Khan et al. 2012, 2017a).

In the present study, two synthetic genes (syncodChi42-1 and syncodChi42-2, NCBI: MT083802 and MT083803) encoding the $42 \mathrm{kDa}$ chitinase, which were optimized plant codon usage from the wild-type chi42 gene (chi42, NCBI: HM191683) of T. asperellum SH16, were agroinfiltrated into leaf of $N$. benthamiana. This optimization was expected to result in higher expression of chitinase in transgenic plants. The high expression levels of the two synthetic chi42 genes and the antifungal activity of the recombinant plant chitinase obtained from this study promise potential applications in the field of transgenic plants against phytopathogenic fungi.

\section{Materials and Methods}

\section{Plant material}

The leaves of six-week-old $N$. benthamiana plants raised in the plant growth chamber (JEIOTECH GC-1000TLH, Korea) at a temperature of $24^{\circ} \mathrm{C}$ and under a light intensity of 3000 lux with $12 \mathrm{~h}$ daylight used to transiently express chi42 genes via agroinfiltration. After Agrobacterium infiltration, plants were grown under the similar condition.

\section{Binary vector}

The chi42 genes consisted of a wild-type gene (chi42) (Loc et al. 2011) and two synthetic genes (syncodChi42-1 and syncodChi42-2) (Luong et al. 2021) containing XbaI and $\mathrm{SacI}$ ends inserted into the same sites of the plant expression vector pMYV719 by removing the CTB-L-S1D segment (Fig. 1). CTB-L-S1D is a fusion protein of cholera toxin (CTB) protein and S1D epitope consisting of a marker peptide (L) employed to analyze the expression of CTB protein in another study (Huy et al. 2016). The pMYV508 vector harboring $p 19$ gene (Fig. 2) was used in combination with the pMYV719/chi42 vector during gene transfer to enhance chi42 expression in $N$. benthamiana. Both pMYV719 and pMYV508 vectors were provided by Prof. Yang Moon-Sik (Chonbuk National University, Republic of Korea).

\section{Infiltration of Agrobacterium}

Triparental mating between A. tumefaciens LBA4404, Escherichia coli containing pMYV719/chi42 and E. coli containing helper plasmid pRK2013 was performed according to Van Haute et al. (1983). Recombinant A. tumefacaciens LBA4404 containing pMYV719 vector harboring one of three chi42 genes and A. tumefacaciens LBA4404 containing pMYV508 vector harboring $p 19$ gene, a suppressor of silencing gene of tomato bushy stunt virus (TBSV), were cultured in $5 \mathrm{~mL}$ YEP (yeast extract peptone) medium (Muli et al. 2017) containing $50 \mu \mathrm{g} / \mathrm{mL}$ kanamycin

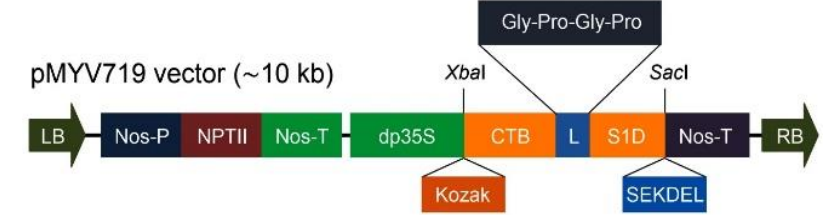

Fig. 1: Vector pMYV719. LB: left border, RB: right border, S1D: S1D epitope, CTB: cholera toxin B subunit, dp35S: duplicated CaMV 35S promoter, Nos-T: terminator of nopaline synthase gene, Nos-P: promoter of nopaline synthase gene, Kozak: consensus sequence, SEKDEL: sequence Ser-Glu-Lys-Asp-GluLeu has been shown to be a signal which leads to retention of at least two proteins in the endoplasmic reticulum, NPTII: neomycin phosphotransferase II gene, L: sequence Gly-Pro-Gly-Pro. The CTB-L-S1D sequence including the Kozak and SEKDEL sequences will be removed from the vector by XbaI and SacI. Chi42 genes will be then inserted into vector at the same sites

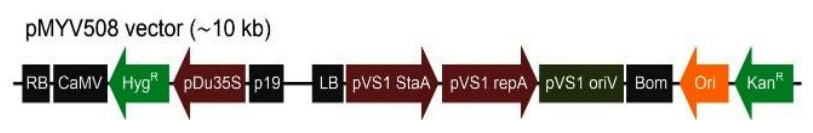

Fig. 2: pMYV508 vector. RB: right border, CaMV: cauliflower mosaic virus, Hyg $^{\mathrm{R}}$ : hygromycin resistant gene, pDu35S: duplication of CaMV 35S promoter, p19: a gene-silencing suppressor gene, LB: left border, pVS1 StaA: stability protein from the plasmid pVS1 that is essential for stable plasmid segregation in Agrobacterium, pVS1 repA: replication protein from the plasmid pVS1 that permits replication of low-copy plasmids in Agrobacterium, pVS1 oriV: origin of replication from the plasmid pVS1 that permits replication of low-copy plasmids in Agrobacterium, Bom: basis of mobility region from $\mathrm{pBR} 322$, Ori: high-copy number origin of replication, $\operatorname{Kan}^{\mathrm{R}}$ : kanamycin resistant gene

and $100 \mu \mathrm{g} / \mathrm{mL}$ rifampicin for 2 days at $28^{\circ} \mathrm{C}$ in dark with a shaking speed of $200 \mathrm{rpm}$. The culture was centrifuged at $6000 \mathrm{rpm}$ for $5 \mathrm{~min}$ to harvest bacterial biomass, then resuspensed by MES buffer (10 $\mathrm{m} M$ 2-[N-morpholino] ethanesulfonic acid, $10 \mathrm{mM} \mathrm{MgSO}$, $\mathrm{pH}$ 5.5) to an OD600 of $0.8-1$. The suspension was then supplemented with 200 $\mu \mathrm{M}$ acetosyringone, followed by incubation in dark for 1-2 $\mathrm{h}$ and finally injected in the abaxial side of the leaves. After 3-7 days of injection, leaves were used for further analysis.

\section{PCR amplification}

Chi42 genes were amplified with specific primers (Table 1). PCR components (for a total volume of $20 \mu \mathrm{L}$ ) consist of $100 \mathrm{ng}$ of DNA template, $10 \mathrm{pmol}$ of each primer and $1 \mu \mathrm{L}$ of $(2 \times)$ PCR Master Mix (Thermo Fisher Scientific). PCR was performed as follows: a genomic denaturation of $95^{\circ} \mathrm{C}$ for $10 \mathrm{~min}$; followed by 30 cycles of $95^{\circ} \mathrm{C}$ for $1 \mathrm{~min}, 55^{\circ} \mathrm{C}$ for $1 \mathrm{~min}$ and $72^{\circ} \mathrm{C}$ for $1 \mathrm{~min}$; finally, an extension of $72^{\circ} \mathrm{C}$ for $10 \mathrm{~min}$.

\section{Western blot analysis}

Leaf samples (approx. $0.5 \mathrm{~g}$ ) from the agroinfiltrated plants 
Expression of Chi42 in Nicotiana benthamiana / Intl J Agric Biol, Vol 26, No 1, 2021

Table 1: Nucleotide sequence of specific primers for PCR amplification of the genes chi42, syncodChi42-1 and syncodChi42-2

\begin{tabular}{|c|c|c|}
\hline Primers & Nucleotide 5'-3' & Expected size of amplicons $(\mathrm{kb})$ \\
\hline syncodChi42-F & GCGCTCTAGAAAAACTAAAAGTAGAAG (27 mer) & \multirow{4}{*}{$\sim 1.3$} \\
\hline syncodChi42-R & GCGCGAGCTCTTAATTCAAACCAGAT (26 mer) & \\
\hline chi42-F & GCGCTCTAGAAAAACTAAAAGTAGAAG (27 mer) & \\
\hline chi42-R & GCGCGAGCTCTTAGTTGAGACCGCTT (26 mer) & \\
\hline
\end{tabular}

were ground in liquid nitrogen and extracted with $1 \mathrm{~mL}$ of phosphate buffer ( $\mathrm{pH} 7)$. An aliquot $(50 \mu \mathrm{g})$ of total soluble protein (TSP) from the extract determined by the Bradford protein assay (1976), was denaturated at $95^{\circ} \mathrm{C}$ for $10 \mathrm{~min}$ before performing sodium dodecyl sulfate-polyacrylamide gel electrophoresis (SDS-PAGE) at $50 \mathrm{~V}$ for $90 \mathrm{~min}$ for stacking gel and then $80 \mathrm{~V}$ for 120 min for separating gel. After the separation, one of the two gels was stained with Coomassie blue while the second gel was blotted onto nitrocellulose membranes (Novex ${ }^{\mathrm{TM}}$ - Thermo Fisher Scientific) using Western Blot Transfer Buffer at $145 \mathrm{~mA}$ for $3 \mathrm{~h}$ on mini-transblot (Bio-Rad, USA).

The blots were firstly treated with $5 \%$ skim milk in Tris buffered saline with Tween 20 (TBST) solution (Sigma-Aldrich) at $37^{\circ} \mathrm{C}$ for $1 \mathrm{~h}$ with a gentle shaking for blocking non-specific linking. The blots were then washed three times with TBST for 15 min each and incubated with first antibody (mouse anti-Ta-CHI42 polyclonal antibody) (Luong et al. 2021) which was diluted 1:2000 in TBST at $37^{\circ} \mathrm{C}$ for $2 \mathrm{~h}$ with gentle shaking.

The blots were washed three times with TBST for 15 min each, and then incubated again with second antibody (goat anti-mouse IgG antibody conjugated with alkaline phosphatase, AbD Serotec - currently Bio-Rad Antibodies) which was diluted $1: 5000$ at $37^{\circ} \mathrm{C}$ for $2 \mathrm{~h}$ with gentle shaking. After washing three times with TBST and once with Tris- $\mathrm{MgCl}_{2}-\mathrm{NaCl}$ buffer (TMN: $100 \mathrm{~m} M$ Tris base $\mathrm{pH}$ 9.5, 5 $\mathrm{m} M \mathrm{MgCl}_{2}$ and $\left.100 \mathrm{mM} \mathrm{NaCl}\right)$, the blots were developed with 5-bromo, 4-chloro, 3-indolylphosphate (BCIP)/nitroblue tetrazolium (NBT) solution (Sigma-Aldrich, Cat No B6404) for $3 \mathrm{~min}$ in the dark. The intensity of the Western blot signal was measured using ImageJ software (V 1.52v).

\section{Chitinase assay}

The chitinolytic action was preliminary evaluated by loading TSP (crude CHI42 enzyme extracted from $N$. benthamiana leaves) into a hole on $1.5 \%$ agar plate containing $1.2 \%$ colloidal chitin as substrate. The agar plate was then kept at $4^{\circ} \mathrm{C}$ for $8 \mathrm{~h}$ to diffuse the enzyme, followed at $28^{\circ} \mathrm{C}$ for $6 \mathrm{~h}$ to hydrolyze chitin, and finally stained with 0.1\% Lugol's solution (Calissendorff and Falhammar 2017) for detection of hydrolysis. Colloidal chitin was prepared according to Murthy and Bleakley (2012).

Chitinase activity was then determined spectrophotometrically at $420 \mathrm{~nm}$ (Tsujibo et al. 1998) with pNpGlcNAc (Merck) as a substrate. Fifty $\mu \mathrm{g}$ of TSP was added to $15 \mu \mathrm{L}$ of $2.5 \mathrm{~m} M$ pNpGlcNAc (4-nitrophenyl Nacetyl- $\beta$-D-glucosaminide) and the enzymatic reaction was performed at $45^{\circ} \mathrm{C}$ for $10 \mathrm{~min}$, then terminated with $1 \mathrm{~mL}$ of $0.2 \mathrm{M}$ sodium carbonate. One unit of chitinase is defined as the amount of enzyme required to release $1 \mu \mathrm{mol} p$ nitrophenol from pNpGlcNAc per min. $p$-nitrophenol purchased from Merck was used to plot the standard curve.

\section{In vitro assay for antifungal activity}

Fungal strain $S$. rolfsii was provided by Department of Plant Protection, Hue University, Vietnam. The effect of CHI42 on the growth of $S$. rolfsii was investigated on $1 / 2$ potato dextrose (PD) solid and liquid medium containing 10-60 $\mathrm{U} / \mathrm{mL}$ of enzyme and about $10^{4}$ fungal spores that cultured at $28^{\circ} \mathrm{C}$ for $36 \mathrm{~h}$. After centrifuging at $4000 \mathrm{rpm}$ for $5 \mathrm{~min}$, the mycelium biomass from the liquid culture was washed with $\mathrm{ddH}_{2} \mathrm{O}$ to determine fresh weight, followed by drying at $65^{\circ} \mathrm{C}$ to a constant mass to determine dry weight.

\section{Statistical analysis}

The experiments were designed in completely randomized design. All observations were repeated three times. The data are expressed as the means, the one-way ANOVA was conducted based on Duncan's test ( $p$-value at 0.05) to compare the statistically significant difference of the means by SPSS software.

\section{Results}

\section{Expression of chi42 genes in agroinfiltrated $N$. benthamiana}

PCR amplification of three chi42 genes (chi42, syncodChi42-1 and syncodChi42-2) in agroinfiltrated $N$. benthamiana plants found DNA bands of approximately 1.3 $\mathrm{kb}$ in size (Fig. 3). Both types of transgenic plants (infiltration and coinfiltration) displayed specific DNA bands of chi42 genes on electrophoretic image. These results confirmed that chi42 genes were successfully transferred into leaves.

SDS-PAGE and Western blot analysis was conducted to determine the expression of chi42 genes in agroinfiltrated $N$. benthamiana plants. Protein bands and signals of antigenantibody interaction with an expected molecular weight of approximately $42 \mathrm{kDa}$ were found on the gels and the blots 


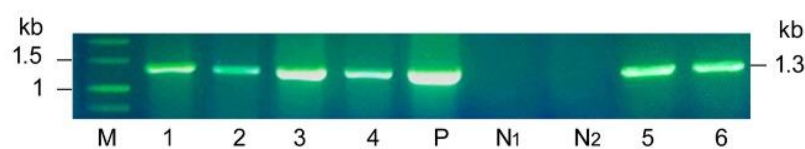

Fig. 3: PCR amplification of chi42 genes from transgenic $N$. benthamiana. 1 and 2 : infiltration and coinfiltration of syncodChi42-1 gene, respectively. 3 and 4: infiltration and coinfiltration of syncodChi42-2 gene, respectively. 5 and 6 : infiltration and coinfiltration of chi42 gene, respectively. P: pUC vector containing chi42 gene as positive control. N1 and N2: wildtype $N$. benthamiana and agroinfiltrated $N$. benthamiana without chi42 insert as negative controls, respectively
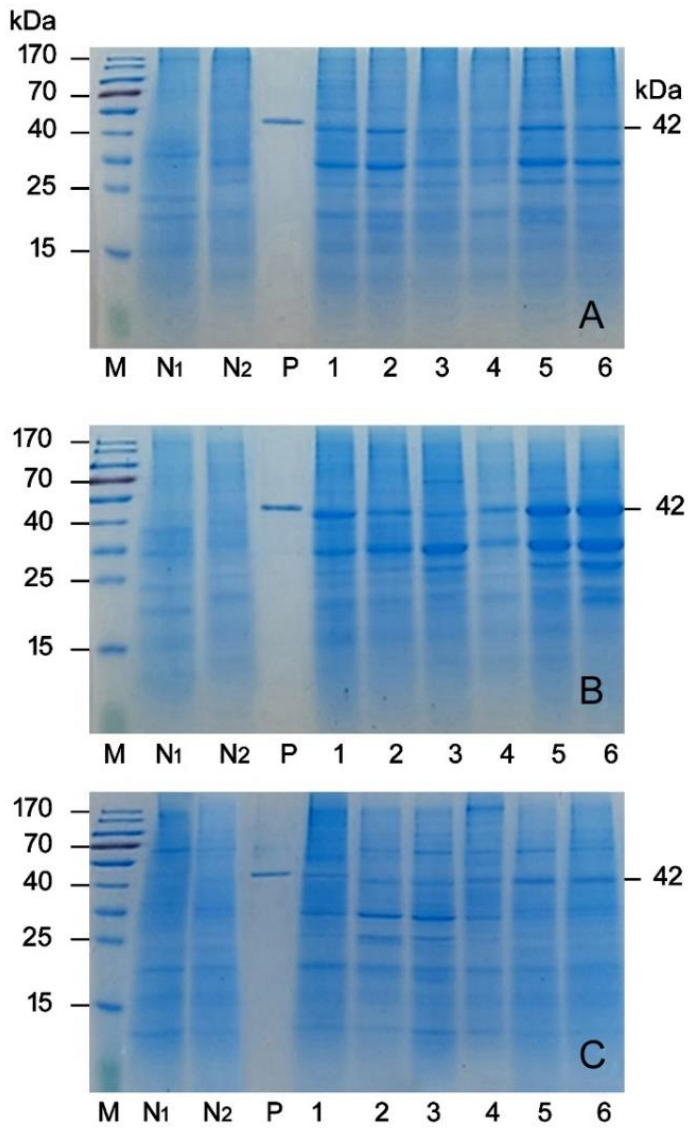

Fig. 4: SDS-PAGE analysis for chi42 genes were agroinfiltrated in N. benthamiana. (A): syncodChi42-1, (B): syncodChi42-2 and (C): chi42. M: Protein molecular weight marker (Thermo Scientific). P: purified bacterial CHI42 enzyme as positive control. N1 and N2: wild-type $N$. benthamiana and agroinfiltrated $N$. benthamiana without chi42 insert as negative controls, respectively. 1-3: after 3,5 and 7 days of infiltration (pMYV719/chi42), 4-6: after 3, 5 and 7 days of coinfiltration (pMYV719/chi42 and pMYV508)

in positive control and transgenic plants (Fig. 4-5). Analysis of signal intensities from Western blot showed that the expression levels of chi42 genes decreased over time from day 3 to day 7 after agroinfiltration with the single vector. In using the vector mixture, the expression levels of synthetic
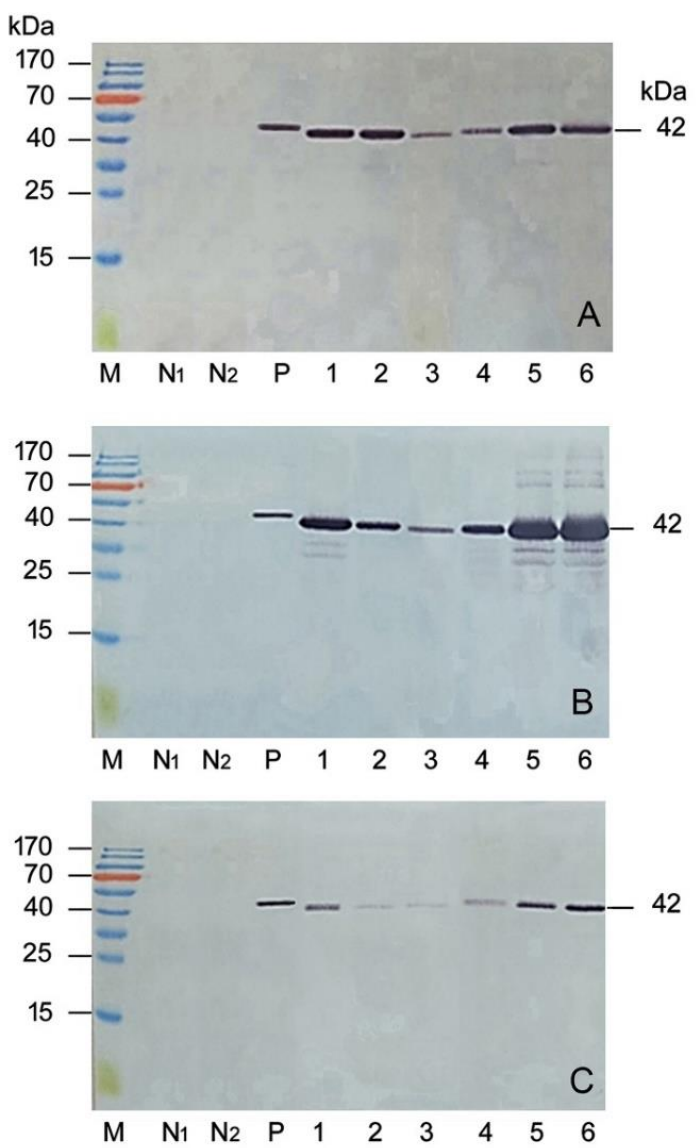

Fig. 5: Analysis of Western blot for chi42 genes were agroinfiltrated in $N$. benthamiana. (A): syncodChi42-1, (B): syncodChi42-2 and (C): chi42. M: Protein molecular weight marker (Thermo Scientific). P: purified bacterial CHI42 enzyme as positive control. $\mathrm{N} 1$ and N2: wild-type $N$. benthamiana and agroinfiltrated $N$. benthamiana without chi42 insert as negative controls, respectively. 1-3: after 3, 5 and 7 days of infiltration (pMYV719/chi42), 4-6: after 3, 5 and 7 days of coinfiltration (pMYV719/chi42 and pMYV508)

chi42 genes increased from day 3 to day 7 (chi42 and syncodChi42-2) or day 5 (syncodChi42-1), later descending in the following days. In general, the use of vector mixture only increased the expression of chi42 and syncodChi42-2 genes in $N$. benthamiana. The highest intensities of the Western signals for syncodChi42-1 gene in N. benthamiana plants agroinfiltrated with single vector and vector mixture were insignificantly different (Fig. 6). Generally, the two synthetic chi42 genes were suitable for plant expression, especially the syncodChi42-2 gene which showed significantly higher levels of expression in Western blot.

\section{Chitinolytic activity of CHI42}

Chitinolytic action of CHI42 enzyme from transgenic $N$. benthamiana was preliminary evaluated by agar plate containing colloidal chitin substrate. The results in Fig. 7A indicated that the difference of the diameter of the clear 


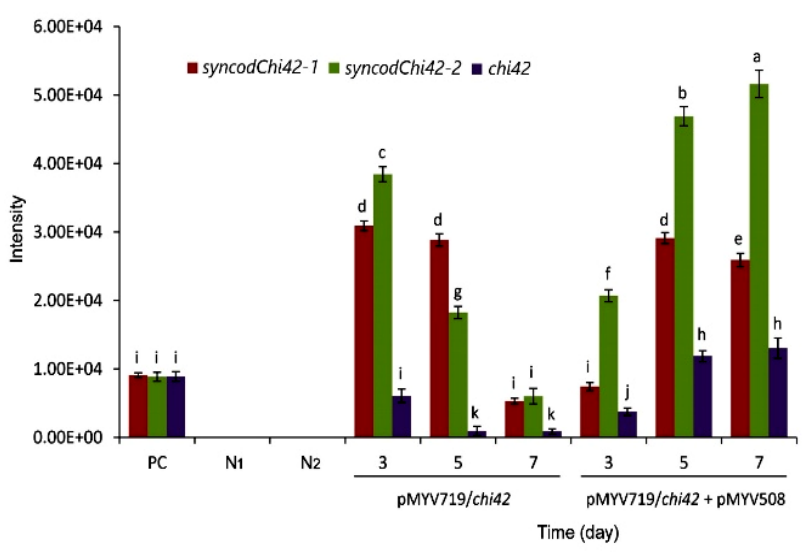

Fig. 6: Intensities of Western blot signals. PC: purified bacterial CHI42 enzyme as positive control. N1 and N2: wild-type $N$. benthamiana and agroinfiltrated $N$. benthamiana without chi42 insert as negative controls, respectively. 3,5 and 7: after 3,5 and 7 days of infiltration (pMYV719/chi42) and coinfiltration (pMYV719/chi42 and pMYV508). Different letters on the chart represent statistically significant differences (Duncan's test, $p<0.05)$

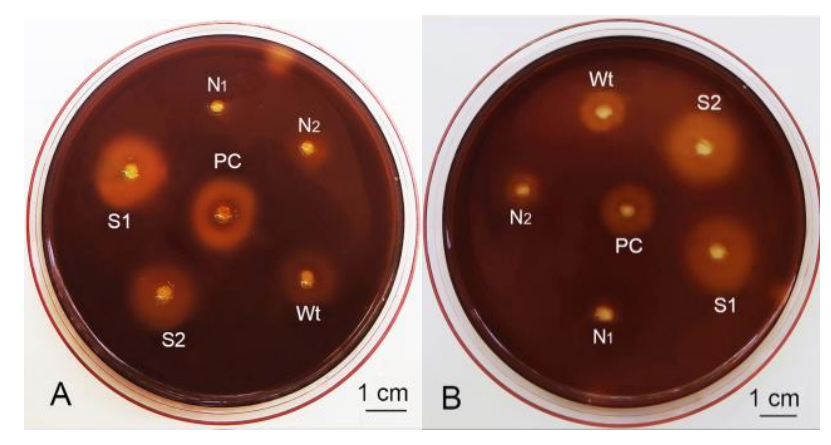

Fig. 7: Chitinolytic activity of plant CHI42 enzyme from different chi42 genes on hydrolytic plate. (A): 3 days after infiltration (pMYV719/chi42), (B): 7 days after coinfiltration (pMYV719/chi42 and pMYV508). S1: syncodChi42-1, S2: syncodChi42-2, Wt: chi42, PC: purified bacterial CHI42 enzyme as positive control, N1 and N2: wild-type $N$. benthamiana and agroinfiltrated $N$. benthamiana without chi42 insert as negative controls, respectively

zone $(D)$ and the diameter of the hole for loading enzyme (d) was about $1.5 \mathrm{~cm}$ (syncodChi42-1) and $1.4 \mathrm{~cm}$ (syncodChi42-2) after 3 days of infiltration; whilst, Fig. 7B showed the broader hydrolytic zones after 7 days of coinfiltrationl, $D$ - $d$ of CHI42 enzymes reached about $1.6 \mathrm{~cm}$ (syncodChi42-1) and $1.9 \mathrm{~cm}$ (syncodChi42-2). The hydrolytic zones of CHI42 enzyme from $N$. benthamiana agroinfiltrated without chi42 inserts or with wild-type chi42 gene in all treatments were weaker than CHI42 enzyme from synthetic chi42 genes.

The chitinolytic activity of the protein extract from transgenic $N$. benthamiana peaked around $290 \mathrm{U} / \mathrm{mL}$ when coinfiltrated by two vectors, pMYV719/ syncodChi42-2 and pMYV508, after 7 days of treatment. The syncodChi42-1 gene also expressed quite high chitinolytic activity with more than $180 \mathrm{U} / \mathrm{mL}$ in $N$. benthamiana after 7 days of coinfiltration; whereas, the highest activity of CHI42 enzyme from $N$. benthamiana containing chi42 gene was about $110 \mathrm{U} / \mathrm{mL}$ in the same treatment, 1.7 and 2.6 times lower than CHI42 enzyme from syncodChi42-1 and syncodChi42-2 genes, respectively (Fig. 8).

Generally, two synthetic chi42 genes showed higher chitinolytic activities when agroinfiltrated into leaves of $N$. benthamiana along with pMYV508 vector. Comparison of chitinolytic activity and level of gene expression in Western blot analysis showed that they seem compatible with each other. The results on a hydrolyzed zone on an agar plate with colloidal chitin used as substrate were similar to that of chitinolytic activity.

\section{In vitro assay for the antifungal activity of CHI42}

Antifungal activity of CHI42 was measured based on its ability to inhibit the growth of mycelium in the pathogenic fungus $S$. rolfsii containing chitin in the cell wall. The antifungal activity of CHI42-1 and CHI42-2 from $N$. benthamiana coinfiltrated by two vectors, pMYV719/synthetic chi42 and pMYV508, after seven days of treatment is shown in Fig. 9 and Table 2. The growth of $S$. rolfsii causing white mold wilt disease was inhibited on medium containing CHI42 (Fig. 9). The fresh biomass of $S$. rolfsii only achieved about $91 \mathrm{mg}$ and $40 \mathrm{mg}$ (about $1 \mathrm{mg}$ and $0.4 \mathrm{mg}$ dry biomass) when they were treated with 60 U/mL of CHI42-1 and CHI42-2, respectively. However, in the chitinase untreated control and the agroinfiltrated control without chi42 insert, the fresh biomass of $S$. rolfsii reached about 1201 and $959 \mathrm{mg}$ (nearby 11 and $9 \mathrm{mg}$ dry biomass), respectively (Table 2 ).

\section{Discussion}

In the present study, the chi42 genes were controlled by cauliflower mosaic virus (CaMV) $35 \mathrm{~S}$ promoter, a promoter that can be activated in different plant tissues (Stockhaus et al. 1989). Transient expression of cre recombinase from bacteriophage P1 in leaves of $N$. benthamiana or antigen staphylococcal endotoxin B in leaves of radish (Raphanus sativus L.) were also driven by $35 \mathrm{~S}$ promoter (Kopertekh and Schiemann 2005; Liu et al. 2018).

It was known that P19 proteins sequester small RNA duplexes, thereby preventing the induction of the silencing pathway (Danielson and Pezacki 2013). Studies have shown that transiently expressed proteins in $N$. benthamiana leaves have a higher yield when coinfiltrated with TBSV p19 (Voinnet et al. 2003). Agrobacterium containing p35S-GSN was coinfiltrated with one of the vectors harboring a viral suppressor of silencing gene (e.g. p35S-TSBV.p19, p35SCMV.2b, C-terminal truncated CMV 2b (1-94), p35SPRSV.HC-Pro or p35S-TLCV.TrAP) significantly increased the transient expression of $\beta$-glucuronidase (GUS) in N. benthamiana (Norkunas et al. 2018). Yamamoto et al. 


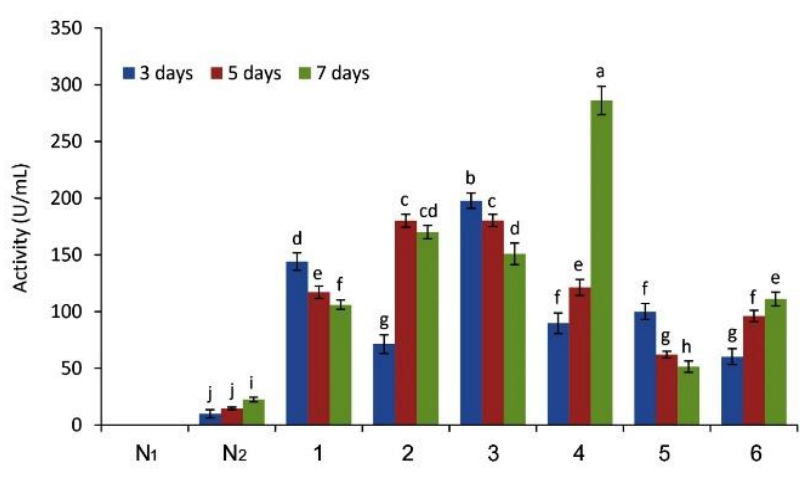

Fig. 8: Chitinase activity of plant CHI42 enzyme from different chi42 genes after 3-7 days of agroinfiltration. N1 and N2: wildtype $N$. benthamiana and agroinfiltrated $N$. benthamiana without chi42 inserts as negative controls, respectively. 1 and 2: infiltration and coinfiltration of syncodChi42-1, respectively. 3 and 4: infiltration and coinfiltration of syncodChi42-2, respectively. 5 and 6: infiltration and coinfiltration of chi42, respectively. Different letters on the chart represent statistically significant differences (Duncan's test, $p<0.05$ )

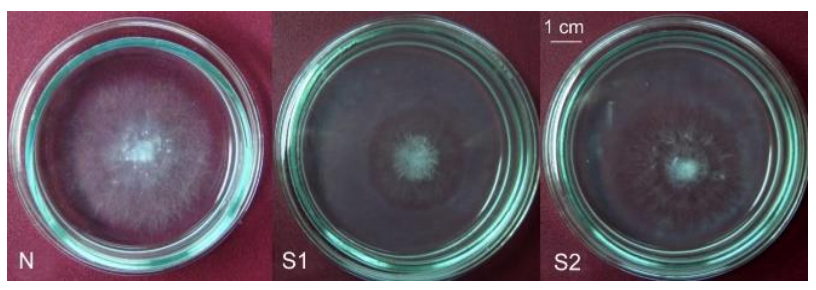

Fig. 9: Antifungal activity assay against $S$. rolfsii of plant CHI42 enzyme from syncodChi42-1 and syncodChi42-2 genes. N: agroinfiltrated $N$. benthamiana without chi42 inserts as negative controls. S1: $60 \mathrm{U} / \mathrm{mL}$ of CHI42 from syncodChi42-1 gene. S2: $60 \mathrm{U} / \mathrm{mL}$ of CHI42 from syncodChi42-2 gene

Table 2: Effect of CHI42 enzyme from syncodChi42-1 and syncodChi42-2 on fresh and dry biomass of $S$. rolfsii mycelium after $36 \mathrm{~h}$ of culture

\begin{tabular}{llcc}
\hline Enzyme & Level (U/mL) & Fresh biomass $(\mathrm{mg})$ & Dry biomass $(\mathrm{mg})$ \\
\hline CHI42-1 & 10 & $902.12^{\mathrm{c}}$ & $7.33^{\mathrm{c}}$ \\
& 20 & $524.67^{\mathrm{d}}$ & $5.19^{\mathrm{d}}$ \\
& 40 & $372.04^{\mathrm{e}}$ & $3.32^{\mathrm{e}}$ \\
& 60 & $91.11^{\mathrm{g}}$ & $0.97^{\mathrm{g}}$ \\
CHI42-2 & 10 & $873.03^{\mathrm{c}}$ & $7.01^{\mathrm{c}}$ \\
& 20 & $504.55^{\mathrm{d}}$ & $5.13^{\mathrm{d}}$ \\
& 40 & $272.82^{\mathrm{f}}$ & $2.40^{\mathrm{f}}$ \\
& 60 & $39.68^{\mathrm{h}}$ & $0.37^{\mathrm{h}}$ \\
Control 1 & $1201.04^{\mathrm{a}}$ & $10.73^{\mathrm{a}}$ \\
Control 2 & $958.88^{\mathrm{b}}$ & $8.84^{\mathrm{b}}$ \\
\hline CHI42-1: CHI42 from syncodchi42-1 gene. CHI42-2: CHI42 from syncodchi42-2 \\
gene. Control 1: CHI42 untreated culture. Control 2: protein extract from \\
agroinfiltrated N. benthamiana without chi42 inserts. Different letters in a column \\
represent a statistically significant difference (Duncan's test, $p<0.05)$
\end{tabular}

(2018) found replication initiator of geminivirus in combination with a double terminator improved obviously transient expression of green fluorescent protein (GFP) in $N$. benthamiana through agroinfiltration. As an alternative method, Zhao et al. (2017) improved the transformation efficiency of infiltration by some factors such as 5azacytidine (AzaC), ascorbate acid (ASC), or Tween-20. These substances when added to infiltration buffer at concentrations of $20 \mu \mathrm{M}$ for AzaC, $0.56 \mathrm{~m} M$ for ASC, or $0.03 \%(v / v)$ for Tween-20 increased GUS expression level in a leaf of $N$. benthamiana.

The genes that encode chitinase from some Trichoderma species such as $T$. harzianum and T. virens have been also transformed into tobacco, potato, cotton and apple against some pathogens such as Alternaria alternata, A. solani, Botrytis cinerea, and Rhizoctonia solani (Lorito et al. 1998; Emani et al. 2003; Schäfer et al. 2012). However, the expression of fungal-derived synthetic chitinase was only found in some reports such as the $\mathrm{NiC}$ gene from Rhizopus oligosporus for Petunia hybrida (Khan et al. 2012), tobacco and tomato (Kong et al. 2014) and Brassica napus (Khan et al. 2017b). This study is therefore probably the first findings of the synthetic chitinase genes derived from $T$. asperellum that has been expressed in plants and demonstrated strong antifungal activity against $S$. rolfsii. Agarwal et al. (2019) also optimized the codon of the bacterial bar gene to express in tobacco. Observations showed that a suitable proportion of optimum codons may be sufficient to reach a high expression of a transgene. If this ratio is exceeded, there is likely to be no significant improvement in gene expression.

Similar to our results, genes such as chitinase from barley (Hordeum vulgare L.) and CeChil from the Australian pine (Casuarina equisetifolia L.) were introduced into potato and tobacco, respectively via Agrobacterium-mediated transformation have exhibited their antifungal activity (Veluthakkal and Dasgupta 2015). On the other hand, a study by Ibrahim et al. (2007) shown that the fungal elicitation increased oleandrin production in the Agrobacterium transformed Nerium oleander cell suspension culture. In the present study, Agrobacterium without chi42 insertion itself also induced chitinase expression in plant cells after infiltration and plants produce enzyme as a defense response based on elicitation, so it slightly inhibited the growth of $S$. rolfsii.

\section{Conclusion}

The efficacy of agroinfiltration for transient expression of CHI42 enzyme encoded by chi42 genes including a wildtype gene and two synthetic genes from $T$. asperellum $\mathrm{SH} 16$ in $N$. benthamiana was determined. Accordingly, coinfiltration expedited the higher expression of recombinant enzymes, whose genes were optimized for codon usage in plant tissues, with the peak found in syncodChi42-2 gene. Plant CHI42 enzyme exhibited a strong antifungal activity against $S$. rolfsii.

\section{Acknowledgments}

This work was supported by National Foundation for 
Science and Technology Development (NAFOSTED), Vietnam (Grant number 106.02-2017.346). The authors would also like to thank Hue University, Vietnam for facilitating this research and Prof. Yang Moon-Sik (Jeonbuk National University, South Korea) for providing the pMYV719 and pMYV508 vectors.

\section{Author Contributions}

NHL designed the experiments and analyzed tha data; NQDT, PTBH, NXH, NHT, DVT, HAT, and NNL performed the experiments; NQDT, PTBH and NXH analyzed the data; NHL prepared the manuscript. All the authors agreed on the final submission.

\section{Conflict of Interest}

All authors declare no conflicts of interest.

\section{Data Availability}

Data presented in this study will be available on a fair request to the corresponding author.

\section{Ethics Approval}

Not applicable in this paper.

\section{References}

Agarwal P, T Gautam, AK Singh, PK Burma (2019). Evaluating the effect of codon optimization on expression of bar gene in transgenic tobacco plants. J Plant Biochem Biotechnol 28:189-202

Aoki Y, S Haga, S Suzuki (2020). Direct antagonistic activity of chitinase produced by Trichoderma sp. SANA20 as biological control agent for grey mould caused by Botrytis cinerea. Cogent Biol 6; Article 1747903

Bradford MM (1976). A rapid and sensitive method for the quantitation of microgram quantities of protein utilizing the principle of protein-dye binding. Anal Biochem 72:248-254

Calissendorff J, H Falhammar (2017). Lugol's solution and other iodide preparations: Perspectives and research directions in Graves' disease. Endocrine 58:467-473

Chen Q, H Lai, J Hurtado, J Stahnke, K Leuzinger, M Dent (2013). Agroinfiltration as an effective and scalable strategy of gene delivery for production of pharmaceutical proteins. Adv Technol Biol Med 1; Article 103

Chen Q, H Lai (2015). Gene delivery into plant cells for recombinant protein production. Biomed Res Intl 2015; Article 932161

Danielson DC, JP Pezacki (2013). Studying the RNA silencing pathway with the p19 protein. FEBS Lett 587:1198-1205

Deguchi M, D Bogush, H Weeden, Z Spuhler, S Potlakayala, T Kondo, ZJ Zhang, S Rudrabhatla (2020). Establishment and optimization of a hemp (Cannabis sativa L.) agroinfiltration system for gene expression and silencing studies. Sci Rep 10; Article 3504

Del Toro F, F Tenllado, BN Chung, T Canto (2014). A procedure for the transient expression of genes by agroinfiltration above the permissive threshold to study temperature-sensitive processes in plant-pathogen interactions. Mol Plant Pathol 15:848-857

Emani C, JM Garcia, E Lopata-Finch, MJ Pozo, P Uribe, DJ Kim, G Sunilkumar, DR Cook, CM Kenerley, KS Rathore (2003). Enhanced fungal resistance in transgenic cotton expressing an endochitinase gene from Trichoderma virens. Plant Biotechnol J 1:321-336
González I, D Infante, B Martínez, Y Arias, N González, I Miranda, B Peteira (2012). Induction of chitinases and glucanases in Trichoderma spp. strains intended for biological control. Biotecnol Appl 29:12-16

Goulet MC, L Gaudreau, M Gagné, AM Maltais, AC Laliberté, G Éthier, N Bechtold, M Martel, MA D'Aoust, A Gosselin, S Pepin, D Michaud (2019). Production of biopharmaceuticals in Nicotiana benthamianaAxillary stem growth as a key determinant of total protein yield. Front Plant Sci 10; Article 735

Guy E, H Boulain, Y Aigu, C Le Pennec, K Chawki, S Morlière, K Schädel, G Kunert, JC Simon, A Sugio (2016). Optimization of agroinfiltration in Pisum sativum provides a new tool for studying the salivary protein functions in the pea aphid complex. Front Plant Sci 7; Article 1171

Huy NX, NQD Tien, MY Kim, TG Kim, YS Jang, MS Yang (2016). Immunogenicity of an S1D epitope from porcine epidemic diarrhea virus and cholera toxin B subunit fusion protein transiently expressed in infiltrated Nicotiana benthamiana leaves. Plant Cell Tiss Organ Cult 127:369-380

Ibrahim AK, S Khalifa, I Khafagi, D Youssef, IM Khan (2007). Stimulation of oleandrin production by combined Agrobacterium tumefaciens mediated transformation and fungal elicitation in Nerium oleander cell cultures. Enzyme Microb Technol 41:331-336

Khan RS, N Kameya, M Mii, I Nakamura (2012). Transgenic Petunia hybrida expressing a synthetic fungal chitinase gene confers disease tolerance to Botrytis cinerea. Plant Biotechnol 29:285-291

Khan MS, SU Sadat, A Jan, I Munir (2017a). Impact of transgenic Brassica napus harboring the antifungal synthetic chitinase $(\mathrm{NiC})$ gene on rhizosphere microbial diversity and enzyme activities. Front Plant Sci 8; Article 1307

Khan A, IA Nasir, B Tabassum, K Aaliya, M Tariq, AQ Rao (2017b). Expression studies of chitinase gene in transgenic potato against Alternaria solani. Plant Cell Tiss Organ Cult 128:563-576

King JL, JJ Finer, LK McHale (2015). Development and optimization of agroinfiltration for soybean. Plant Cell Rep 34:133-140

Kong K, S Makabe, VO Ntui, RS Khan, I Nakamura (2014). Synthetic chitinase gene driven by root-specific LjNRT2 and AtNRT2.1 promoters confers resistance to Fusarium oxysporum in transgenic tobacco and tomato. Plant Biotechnol Rep 8:151-159

Kopertekh L, J Schiemann (2005). Agroinfiltration as a tool for transient expression of cre recombinase in vivo. Transgenic Res 14:793-798

Leuzinger K, M Dent, J Hurtado, J Stahnke, H Lai, X Zhou, Q Chen (2013). Efficient agroinfiltration of plants for high-level transient expression of recombinant proteins. $J$ Vis Exp 77; Article 50521

Limón MC, MR Chacón, R Mejías, J Delgado-Jarana, AM Rincón, AC Codón, T Benítez (2004). Increased antifungal and chitinase specific activities of Trichoderma harzianum CECT 2413 by addition of a cellulose binding domain. Appl Microbiol Biotechnol 64:675-85

Liu PF, Y Wang, RG Ulrich, CW Simmons, JS VanderGheynst, RL Gallo, CM Huang (2018). Leaf-encapsulated vaccines: Agroinfiltration and transient expression of the antigen staphylococcal endotoxin B in radish leaves. J Immunol Res 2018; Article 3710961

Loc NH, HT Quang, NB Hung, ND Huy, TTB Phuong, TTT Ha (2011). Trichoderma asperellum chi42 genes encode chitinase. Mycobiology 39:182-186

Lorito M, SL Woo, IG Fernandez, G Colucci, GE Harman, JA Pintor-Toro, E Filippone, S Muccifora, CB Lawrence, A Zoina, S Tuzun, F Scala (1998). Genes from mycoparasitic fungi as a source for improving plant resistance to fungal pathogens. PNAS 95:7860-7865

Luong NN, NQD Tien, NX Huy, LQ Man, PTB Hoa, DDH Sinh, NH Tue, DV Thanh, DTK Chi, NH Loc (2021). Expression of $42 \mathrm{kDa}$ chitinase (Ta-CHI42) of Trichoderma asperellum from a synthetic gene in Escherichia coli. FEMS Microbiol Lett (sub)

Mohamed HAA, MH Wafaa, AG Attallah (2010). Genetic enhancement of Trichoderma viride to over produce different hydrolytic enzymes and their biocontrol potentially against root rot and white mold diseases in plants. Agric Biol J N Am 1:273-284

Muli JK, C Mweu, N Budambula, SE Anami (2017). Yeast extract peptone based co-cultivation media promotes transient GUS expression in tropical maize genotypes. Asian J Crop Sci 9:71-81 
Murthy N, B Bleakley (2012). Simplified method of preparing colloidal chitin used for screening of chitinase - producing microorganisms. Internet J Microbiol 10; Article 13823697

Norkunas K, R Harding, J Dale, B Dugdale (2018). Improving agroinfiltration-based transient gene expression in Nicotiana benthamiana. Plant Methods 14; Article 71

Santi L, L Batchelor, Z Huang, B Hjelm, J Kilbourne, CJ Arntzen, Q Chen, HS Mason (2008). An effcient plant viral expression system generating orally immunogenic Norwalk virus-like particles. Vaccine 26:1846-1854

Sámi L, T Pusztahelyi, T Emri, Z Varecza, A Fekete, A Grallert, Z Karanyi, L Kiss, I Pócsi (2001). Autolysis and aging of Penicillium chrysogenum cultures under carbon starvation: Chitinase production and antifungal effect of allosamidin. J Gen Appl Microbiol 47:201-211

Schäfer T, MV Hanke, H Flachowsky (2012). Chitinase activities, scab resistance, mycorrhization rates and biomass of own-rooted and grafted transgenic apple. Genet Mol Biol 35:466-473

Shamloul M, J Trusa, V Mett, V Yusibov (2014). Optimization and utilization of Agrobacterium-mediated transient protein production in Nicotiana. Jove-J Vis Exp 86; Article 51204

Stockhaus J, J Schell, L Willmitzer (1989). Correlation of the expression of the nuclear photosynthetic gene ST-LS1 with the presence of chloroplasts. EMBO J 8:2445-2451

Suzaki T, M Tsuda, H Ezura, B Day, K Miura (2019). Agroinfiltrationbased efficient transient protein expression in leguminous plants. Plant Biotechnol 36:119-123
Tsujibo H, N Hatano, T Mikami, A Hirasawa, K Miyamoto, Y Inamori (1998). A novel $\beta$-N-acetylglucosaminidase from Streptomyces thermoviolaceus OPC-520: Gene cloning, expression and assignment to family 3 of the glycosyl hydrolases. Appl Environ Microbiol 64:2920-2924

Van Haute E, H Joos, M Maes, G Warren, M Van Montagu, J Schell (1983). Intergeneric transfer and exchange recombination of restriction fragments cloned in pBR322: A novel strategy for the reversed genetics of the Ti plasmids of Agrobacterium tumefaciens. EMBO J 2:411-417

Veluthakkal R, MG Dasgupta (2015). Agrobacterium-mediated transformation of chitinase gene from the actinorhizal tree Casuarina equisetifolia in Nicotiana tabacum. Biologia 70:905-914

Voinnet O, S Rivas, P Mestre, D Baulcombe (2003). An enhanced transient expression system in plants based on suppression of gene silencing by the p19 protein of tomato bushy stunt virus. Plant J 33:949-956

Wroblewski T, A Tomczak, R Michelmore (2005). Optimization of Agrobacterium mediated transient assays of gene expression in lettuce, tomato and Arabidopsis. Plant Biotechnol J 3:259-273

Yamamoto T, K Hoshikawa, K Ezura, R Okazawa, S Fujita, M Takaoka, HS Mason, H Ezura, K Miura (2018). Improvement of the transient expression system for production of recombinant proteins in plants. Sci Rep 8; Article 4755

Zhao H, Z Tan, X Wen, Y Wang (2017). An improved syringe agroinfiltration protocol to enhance transformation efficiency by combinative use of 5-azacytidine, ascorbate acid and Tween-20. Plants 6; Article 9 